\title{
Breaking Up the "Religious" Conflict: Some Comparative Perspectives
}

\author{
Bakhruddin Fannani
}

Dosen Tetap Fakultas Tarbiyah UIN Malang

\begin{abstract}
Abstrak
Sebenarnya, kita dapat meminimalisasi-atau malah menghentikan-berbagai "konflik" antar-agama, karena semua agama memiliki hubungan yang sangat kuat dengan masyarakalnya. Artinya, setiap agama -doktrin, dogma, ajaran, dan praktikpraktik-memiliki kesempatan yang sama untuk mempengaruhi masyarakat. Bagaimana pun, hal ini perlu diupayakan secara lebih serius aleh semua pihak.
\end{abstract}

\section{Introduction}

In normative terms, all religions in the world teach human beings to love and show affection, brotherhood, happiness, and righteous in order to help them live together in peace and harmony. One of the Ten Commandment tells the Jews not to kill others, as do the Holy Bible and the Holy Quran. A declaration about the relation of the Church to non-Christian religions was proclaimed by his holiness, Pope Paul VI, on October 1965: "The church, therefore, exhorts his sons, that through dialogue and collaboration with the followers of other religions, carried out with prudence and love an in witness to Christian faith and life, they recognize, preserve and promote the good things, spiritual and moral, as well as 
the socio-cultural values found among these men." However, some people try to use religion to justify violence. They choose a piece of the verse of the Holy Quran or the Holy Bible instead looking at the whole. They use religious arguments to justify violence which is done in the name of some good and often in the name of God. Henceforth, this violence causes many "religious" conflict in the world. This is why it is so important to try to understand why "religious" conflict are occuring and how they can be overcome.

This paper will give an explanation about the original of these conflict which emerged from competition of political leaders; multicultural societies and modernism. It also discusses ways to break up these "religious" conflict, for instance, peace movement which was adapted from Gandhi's experience in India; education of religious doctrine in the big picture by using leaders and educators, religious institutions, the preaching of tolerance and understanding in places of worship; and government intervention in meeting basic human needs and providing opportunities for advancement (redistribution of wealth), and maintaining peace.

\section{The Origion of "Religious" Conflict}

"Religious" conflicet as meant here is not conflict between religions, their doctrines, dogmas, and practices, but instead conflict in the name of religion. Religious doctrines and practices, however different seldom have given rise to actual conflict. In the last decade 'religious' conflicts have assumed greater significance than before. Especially, because a religious resurgence was took place in politics and society. At the same time, societies which were once largely mono-religious are now becoming multi-religious and have to grapple with new problems and new challenges.

Concerning the emergence of religious conflicts, Ronald L. Johnstone offers a historical explanation. This conflict was the continuous warfare and battle mentioned in the Old Testament between Israelites and their 'enemies'. A fundamental reason for this warfare was the fact that Israelite, after their escaping from Egypt, tried to occupy the land which was inhabited by others. They believed that they were God's chosen people and were given special assistance. So, they had to do battle not against Israel's political enemies but against worshippers of false god. Moreover, in the middle ages there were armed religious conflicts 
which were defined by the participants as 'holy wars' between European Christian and the Muslim (infidels) who had occupied God's sacred ground (Palestine).

Johnstone also provide contemporary examples of religious conflict. There has been a several series of warfare between Protestant and Roman Catholic in Northern Ireland which has been continuing for seventy years. Another example is the war between black people and white apartheid in the Union of South Africa; of course the classic example is the religious groups waging war in Lebanon between Christian, Shi'ite, Muslim, and Druze. Johnstone argues that almost every continent has a wellknown example to display. He asserted: "Religion not only might provide solace and comfort and explanations for complex and puzzling issues, but it can also create or at least enhance stress, anxiety, and worry, guilty consciences, and sexual "hangups". This perspective also emphasizes the competition and antagonisms, even outright physical conflict, that exist among both individual and so groups in society, even among religious people and their groups." $(1975,109)$ Hence, stress, anxiety, and guilty consciences have trigged a revolt and often conflicts between religious people.

We have to keep alert about the emergence of interreligious conflict, particularly the conflict in the name of religion, because religious people and purposes deteriorate easily, especially, if they are led by unresponsible people looking for his personal gains.

\section{Competition of Political Leaders}

It should be noted that 'religious' conflict is often between religionists, not religions, and not who participate in religious riots are religious. Religion was taken as political comodity and then become origin of conflicts, both intrareligious and interreligious conflicts. Many rioters who shout religious slogans are often totally ignorant of their religious teaching. They often used religious argument to justify their violence. Violence usually done in the name of some good, and often in the name of God. (Kurtz, 1995, 215) Muzaffar said, "In practice some of them may even be leading lives which are at variance with the moral precepts of the religions they profess." To illustrate this, we can see the tensions, riots, and bloodshed which occurred in many provinces of Indonesia; particularly in Ambon, Molucas, and Aceh. 
Elite politic leaders still despite debating to let fall others and strengthen their own position. They were very attentive to the victim of their conflicts. Moreover, the protracted economic crisis and uncertainty of political situation threatened the disintegration of this multi-religious country. In brief, in the mid of crisis, Indonesian people losed their figure who restrained the political, social, and economic condition.

Electoral politic and elite manipulation of mass sentiments have had an adverse impact upon religious communities in those places. With the advent of competitive party politics in these multi-religious societies, party leaders try to mobilise support and maximise their popularity by exploiting the fears and hopes of that religious communities.

Elite manipulating of majority religious sentiment for electoral purposes not only occurred in Indonesia. The ruling Malay-Muslim elite in Malaysia have also, on certain occasions, exploited the religious sentiments of the majority community with the aim of preserving and perpetuating its political dominance.

Muzaffar explained: "In the October 1990 general elections, for instance, members of this elite fearing that their ruling coalition might lose its two-thirds majority in parliement whipped up irrational, unfounded Muslim fears of a Christiancum-Chinese challenge to the political position of the indigenous Malays. They succeeded in creating a 'siege mentality' within their community as a result or which it rallied around the elite and gave the ruling coalition the victory it wanted."

\section{Modernism and Multiculturalism}

It should be mentioned here that modernism and multicultural ism also cause the religious conflict.

Modernism. Modernism is the emergence of the global, scientific, and technological culture. Many European intellectuals in the nineteenth century often considered religion to be dying because of scientific and domestic revolutions. Galileo's case, for instance, was the example of scientific development and how it challenged the church reputation and entire social order in XVII of the Common Era. French Revolution in XVIII of the C.E. was also a challenge against the 
church which always supported the status quo in the sense of democratic development. (Kurtz, 1995, 151-152)

Kurtz insisted: "This conflict began in the seventeenth century, when church authorities charged the famous scientist Galileo with heresy because he contended that the earth revolved arround the sun, and not vice versa. The Jesuit inquisitors forced Galileo to recant, and his 'heretical' ideas." (1995, 152) Mani of Kurtz's explanation of this problem show that modernism war reacted to by fanaticism. The battle began between the Roman Catholic church and modernism. During the First Vatican Council (1899 C.E.), the highest authorities of the Catholic were declared infallible in matters of faith for the first time in the history of the church. The council campaigned against the modernism, and criticized modern science, democracy, and religious practice in new social circumtances.

Multiculturalism. History tells us that religious conflict before the era of colonialism was less frequent and even less intense. As modern culture emerged and many cultures competed each other, changes were brought about and, suddenly within religious communities surfaced tension and riots. Kurtz asserts: "The cultural life of the global village is a product of an interaction of religious traditions among themselves as well as between each tradition and the multitude of others within which they came into contact as the global society emerged." $(1995,167)$

From the perspective of Kurtz, multiculturalism is a product of ongoing encounters among many religious tradition in the world. Many religious movement struggle against the hegemony of modern cultural centers. "Movement in the Islamic world used centuries-old themes Muslim-non-Muslim as vehicle for expressing their discontent about the invasion of their lives by Christian from the West, Marxist from the Soviet Union, Hindhus from Delhi, and the like ProtestanCatholic cleavanges in the Northern Ireland reflect economic and political division that parallel deep religious differences." (1995, 173)

All these statements indicated that modernism and multiculturalism caused the emergence of religious conflicts which involved the people of various religions in the world. 


\section{The Breaking Up of "Religious" Conflict}

The way to overcoming those religious conflicts is difficult. However, we have to strive for that way. Though there has been conflict in the name of religion, we must recognize tha on the whole different religious communities have lived side by side in various parts of Asia, particularly in multi-religious countries Indonesia, whithout having confrontation between one another. Many countries, in fact, have not known any serious religious conflict.

Before exploring further ways of breaking up the 'religious' conflict which has emerged for reasons mentioned previously, it is necessary to see the social functions of religion, because the problems of religion can not be separated thoroughly from the social life. At least, form Durkheim's point of view on social function of religion we can place religion in its proportional place, and not use it as an excuse for violence. In the perspective of Durkheim's work the scocial function of religion can be explained as: (1) Social solidarity. Religion functions as a form of social cement. Religion can unite the people by bringing them to the rituals and providing them the values and beliefs that tie them into community. (2) Provision of meaning. Religion provides a meaningful answers to the question about existence, and the purpose to a universe. (3) Social control. Religion explains the most important values and norms of a society. (4) Social change. Religion can inspire facilitate a social change. (5) Psychological support. Religion provide individuals with emotional support in uncertainty of the world. (Robertson, 1983, 406-407)

On the other hand, it is important for religious leaders to develop their understanding about the condition of society. Religion should be made accountable for concrete society with its problems. Hence, they can play their role as an effective instrument for breaking up 'religious' conflict.

In breaf, religious conflict must to be overcome using a variety of means.

\section{Education of Religious Doctrine in the Big Picture}

Education doctrine in the big picture-in comprehensive picture and not in restricted view - is directly connected to 'religious' conflict. However, those conflicts frequently emerged from narrow understanding of the religious doctrine.

Ulul Albab, Vol. 5 No. 2, 2004 
The adherents of certain religion often used their religious doctrine as a justification of their violence. Whereas violence, in the perspective of all religion is criticized because it is (1) against human nature, or the nature of things in the universe; (2) ineffective in the long run because it simply produces a spiral of violence; (3) sinful or unjust, and the deity does not like it. (Kurtz, 1995, 218-219)

To start with, there will have to be comprehensive explanations of religious doctrine in the broad picture aimed at reducing potential areas of religious conflict. The religious leaders and educators of each religions, through their religious institution should propose their followers to reach a comprehensive understanding abotur their religious doctrine. They can preach tolerance and understanding of other faiths, then, put this understanding in a framework globalization of solidarity.

Every elite political leader should not think of his or her political position or use religious sentiment for his or her individual electoral purposes.

\section{Peace Movement of Gandhi}

If we take a longer and wider view of history, we can see that religious itistitution or their adherents have not only justified violence, they have frequently criticized it. Mahatma Gandhils movement tried to combine all three arguments against violence: (1) He claims tha nonviolence is the law of universe. (2) Gandhi demonstrated that nonviolense can work even in the most unlikely situation. (3) Gandhi believed that nonviolence was morally superior to violence, and must be carried out even if one feels as if one is acting alone. (Kurtz, 1995, 221)

Gandhi's peace movement is a significant model for the religious conflict resolution and mediation in the middle of modern political movements. In addition, there are the example of the Tibetan Buddhist leader Tenzin Gyatso (Dalai Lama) movement which was filled with compassion, promoted affection, and went far away from violence; the Philipines "People Power" movement which copied the concept from the Hindhu mooring; and Martin Luther King, Jr., who adapted a strategy of non violence from Gandhi for American context. King and others in the civil rights movement also have taken the spirit in the Black Church to encourage the people to struggle against the racism of the system in the United 
States. (Kurtz, 223-227) Other nonviolent protests in Asia and Europe should also not be overlooked.

In this term we should adapt the spirit of the Gandhi's Peace Movement among the ways of breaking up the religious conflicts.

\section{Government Intervention}

What is equally important to overcome the problem of religious conflict is government intervension. As was mentioned above, its critical that elite political leaders consider their followers and disregard of their political competition and their own political agenda.

The government has to meet basic needs and open the opportunities for advancement of its people by the redistributing of wealth. It has to facilitate the establishment of socio-political and economic conditions, not perform interreligious dialogues in small group only. The people need clean water, healthy house, and adequate education. Creating serenity of the people in multi-religious and developing countries was not only a matter of system from above. It must come from below level, through concern for the people's basic need.

In addition, the government has to maintain peace in the fragile relationship among the adherent of religions, particularly in certain places where religious conflicts have happened in the past.

\section{Conclusion}

From the explanation above, we can get the picture of the causes of religious conflicts, like competition of elite political leaders; modernism and multiculturalism. At the same time, the ways for breaking up those conflicts were offered.

In fact, we can stop those conflicts as soon as we want to do it, because every religion has a close relationship with the society. It means that every religion -doctrine, dogmas, and practices- presents a good opportunity to influence society. However, it has to be realized seriously. 


\section{Bibliography}

Ronald L. Johnstone, Religion in Society, Prentice Hall, New Jersey, 1975

Turner, Bryan, S., Religion and Social Theory, Second Edition, Sage Publications, London, 1991.

Kurtz, Lester R., Gods in the Global Village, Pine Forge Press, London, 1995.

Pals, Daniel L., Seven Theories of Religion, Oxford University Press, New York, 1996.

Berger, Peter L., Langit Suci, Agama Sebagai Realitas Sosial, LP3ES, Jakarta, 1991.

Robertson, Ian, Sociology, Worth Publishers, New York, 1983.

Muzaffar, Chandra, Religious Conflict, Kuala Lumpur, Malaysia. 